\title{
PENGARUH PEMBERIAN JUS KULIT DELIMA MERAH (Punica granatum) TERHADAP KADAR LDL DAN HDL WANITA DISLIPIDEMIA
}

\author{
Guruh sarjana, Deny Yudi Fitranti*) \\ Program Studi Ilmu Gizi Fakultas Kedokteran Universitas Diponegoro \\ Jl.Dr.Sutomo No.18, Semarang, Telp (024) 8453708, Email : gizifk@ undip.ac.id
}

\begin{abstract}
Background: Dyslipidemia was one of risk factor for cardiovascular disease. Pomegranate peel contained anthocyanin which have beneficial effect to increase the HDL content. This study aimed to examine the LDL and $H D L$ rate difference between control and intervention for effect of pomegranate peel juice intervention (Punicagranatum) in 30-49 years old Dyslipidemic women.

Methode: This quasi experiment study designed with "pre-post control gorup" design. Subjects of study were dyslipidemic women with $L D L$ cholesterol rate $\geq 200 \mathrm{mg} / \mathrm{dl}$ and $H D L$ cholesterol rate $\leq 40 \mathrm{mg} /$ dl, intervention group get 25 g/day of pomegranate peel juice and the control group get placebo for 14 days. Phosphotungsticprecipilation methode have been used for analyze the LDL and HDL cholesterol content. Blood sample retrieved after subject of the study had fasting for 10 hours long. Normalitiy test for mean intake of energy, protein, fate, carbohydrate, fiber and cholesterol, So do for variable like Physical activity, LDL and HDL cholesterol rate before-after intervention were using shapiro-wilk. Statistical analysis of pre-post LDL and HDL cholesterol content in intervention and control group consecutively conducted by using dependent t-test, whereas the control group using non-paramteric test (wilcoxon test). Double linear regression test was conducted for estimating the the effect of nutrient intake and physical activity toward LDL and HDL cholesterol rate.

Result : Percentage of the 40-49 years old dyslipidemic subject were included in overweight status 24,7\%, and obesity status 25,55\%. Physical activity were included in moderate category for all subject in intervention and control group group, whereas 37,5\% low category and 62,5\% moderate category for physical activity were found in control group. Alteration of LDL cholesterol mean rate in intervention and control group consecutively were

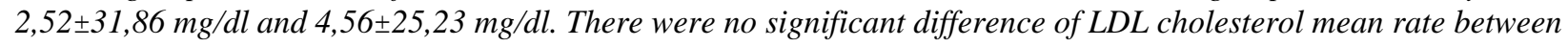
intervention and control group $(p>0,05)$. Alteration of HDL cholesterol mean rate in intervention and control group consecutively was $0,00 \pm 6,80 \mathrm{mg} / \mathrm{dl}, 2,25 \pm 3,8 \mathrm{mg} / \mathrm{dl}$. There were no significant difference of $\mathrm{HDL}$ cholesterol mean rate between intervention and control group $(p>0,05)$. The alteration of LDL cholesterol rate $(61,5 \%)$ affected by protein intake, where as the HDL Cholesterol rate alteration $(26,1 \%)$ affected by fiber intake.

Conclusion: The 14 days-25 gr/day of pomegranate peel juice treatment insignificantly affect the LDL and HDL cholesterol rate of the 40-49 years old Dyslipidemic women. There was a 2,52 mg/dl decreasing of LDL cholesterol rate, but HDL cholesterol didn't.
\end{abstract}

Keywords : pomegranate peel juice; LDL; HDL; Dyslipidemia

\begin{abstract}
ABSTRAK
Latar Belakang : Dislipidemia merupakan salah satu faktor risiko terjadinya penyakit jantung dan pembuluh darah. Kulit delima mengandung anthocyanin yang dapat meningkatkan kadar HDL dan menurunkan kadar LDL. Penelitian ini bertujuan untuk mengetahui perbedaan kadar LDL dan HDL wanita usia 30-49 tahun yang diberi dan tidak diberi jus kulit delima (Punica granatum).

Metode : Penelitian ini merupakan penelitian quasi experimental dengan rancangan pre-post control group design. Subjek adalah wanita dislipidemia dengan kadar kolesterol $L D L \geq 130 \mathrm{mg} /$ dl dan kadar kolesterol HDL $\leq 40$ mg/dl, Kelompok perlakuan mendapat $25 \mathrm{~g} / \mathrm{hari}$ jus kulit delima dan kelompok kontrol mendapat plasebo. Perlakuan dilakukan selama 14 hari. Metode phosphotungstic precipilation digunakan untuk menganalisis kadar kolesterol HDL dan LDL sebelum dan setelah perlakuan, darah diambil setelah subjek berpuasa selama 10 jam. Uji beda kadar LDL dan HDL sebelum dan setelah perlakuan pada kelompok perlakuan menggunakan uji dependent $t$ test dan uji beda kadar kolesterol LDL dan HDL sebelum dan setelah perlakuan pada kelompok kontrol menggunakan uji non parametric Wilcoxon. Uji regresi linier berganda dilakukan untuk memprediksi besar pengaruh asupan zat gizi dan aktifitas fisik terhadap kadar LDL dan HDL.

Hasil : : Dislipidemia sebagian besar terdapat pada wanita usia 40-49 tahun dan status gizi overweight sebesar $24,7 \%$ dan obesitas 25,55\%. Aktivitas fisik subjek pada kelompok perlakuan 100\% dalam kategori sedang, sedangkan pada kelompok kontrol 37,5\% dalam kategori rendah dan 62,5\% dalam kategori sedang. Rerata penurunan kadar kolesterol LDL pada kelompok perlakuan sebesar 2,52+31,86 mg/dl dan kelompok kontrol sebesar 4,56+25,23 mg/dl. Rerata penurunan kadar kolesterol LDL antara kelompok perlakuan dan kontrol tidak terdapat perbedaan $(p>0,05)$.
\end{abstract}

\footnotetext{
${ }^{*}$ Penulis Penanggungjawab
} 
Rerata perubahan kadar kolesterol HDL pada kelompok perlakuan sebesar 0,00+6,80 mg/dl dan kelompok kontrol sebesar 2,25+3,80 mg/dl. Rerata perubahan kadar kolesterol HDL antara kelompok perlakuan dan kontrol tidak terdapat perbedaan ( $p>0,05)$. Perubahan kadar LDL 61,5\% dipengaruhi oleh asupan protein. Perubahan kadar HDL 26,1\% dipengaruhi oleh asupan serat.

Kesimpulan : Pemberian jus kulit buah delima selama 14 hari dengan dosis 25 gram/hari pada wanita dislipidemia tidak berpengaruh terhadap kadar LDL dan HDL. Namun terjadi penurunan kadar LDL sebesar 2,52 mg/dl sedangkan kadar HDL tidak terjadi perubahan.

Kata kunci : jus kulit delima; LDL; HDL; dislipidemia

\section{PENDAHULUAN :}

Dislipidemia merupakan kelainan metabolisme lipid yang ditandai dengan peningkatan maupun penurunan fraksi lipid. Kelainan fraksi lipid ditandai dengan peningkatan kadar kolesterol total, Low-density lipoprotein (LDL), trigliserida dan penurunan kadar Highdesity Lipoprotein (HDL). Dislipidemia merupakan salah satu faktor terjadinya penyakit jantung dan pembuluh darah. ${ }^{1}$

Profil Kesehatan Jawa Tengah tahun 2011 melaporkan dari total 1.409 .857 kasus penyakit tidak menular terdapat $62.43 \%$ atau 880.193 kasus penyakit jantung dan pembuluh darah. Rekapitulasi data kesakitan tahun 2012 Dinas Kesehatan Kota Semarang melaporkan terdapat 8.462 kasus penyakit jantung dan pembuluh darah., ${ }^{2,3}$

Kejadian penyakit jantung dan pembuluh darah, dapat diprediksi berdasar nilai LDL dan HDL. LDL mengandung kolesterol sebesar $45 \%$ yang dapat mengendap pada arteri sedangkan HDL mengandung kolesterol sebesar 20\%. HDL berperan mengambil kelebihan kolesterol untuk dibawa ke hati kemudian diproses dan dibuang bersama cairan empedu. Jadi untuk memperkecil risiko atherosklerosis perlu diusahakan kadar LDL rendah dan HDL tinggi. ${ }^{4}$

Faktor risiko yang dapat mempengaruhi terjadinya dislipidemia adalah kelebihan asupan lemak jenuh. Asupan lemak jenuh yang berlebih dapat mempengaruhi proses biosentesis kolesterol. ${ }^{1}$ Pengaturan pola diit untuk menurunkan kadar kolesterol dilakukan dengan mengontrol asupan zat gizi secara seimbang sesuai dengan kebutuhan. Pengaturan pola diit seperti meningkatkan asupan serat dan antioksidan dapat memperbaiki profil lipid. Asupan serat dan antioksidan banyak bersumber dari buah dan sayur. Kandungan antioksidan yang terdapat pada buah dan sayur berupa flavonoid. ${ }^{5,6}$

Flavonoid memiliki banyak pengaruh terhadap kadar profil lipid. Salah satu pengaruhnya yaitu mengaktifkan enzim yang mengikat kolesterol sehingga dapat menekan kadar kolesterol LDL. Flavonoid terdiri dari 6 kelompok utama yaitu chalone, flavon, flavonol, flavonon, anthocyanin dan isoflavonoids. Penelitian terdahulu menunjukan bahwa pemberian $160 \mathrm{mg}$ anthocyanin yang diberikan dua kali/hari selama 12 minggu pada wanita dislipidemia usia 40-65 tahun terbukti dapat menurunkan kadar kolesterol total sebesar $5,7 \mathrm{mg} / \mathrm{dl} .^{7,8}$

Buah delima (Punica granatum) merupakan buah yang kaya akan kandungan flavonoid anthocyanin yang terdapat pada kulit, daging dan biji. Kandungan flavonoid dan anthocyanin pada kulit delima 3 kali lebih tinggi dibandingkan pada bagian daging dan bijinya yaitu sebesar 51,02 $\pm 10,33 \mathrm{mg} / \mathrm{g} .{ }^{9}$

Berdasarkan penelitian di mesir yang dilakukan pada tikus dengan pemberian kulit delima dengan dosis $250 \mathrm{mg} / \mathrm{kg}$ berat badan tikus selama 4 minggu dapat menurunkan kadar LDL sebesar 48,26 mg/dl dan menaikan kadar HDL sebesar $9,8 \mathrm{mg} / \mathrm{dl} .{ }^{10}$ Jika menurut penelitian terdahulu yang menggunakan suplemen anthocyanin, maka penelitian ini menggunakan kulit delima segar dengan dosis $25 \mathrm{~g}$ per hari selama 14 hari. Dosis pemberian kulit delima didapat dari perbandingan berat kulit delima segar dan kering $25: 7 .^{7}$

Penelitian ini bertujuan untuk mengetahui pengaruh pemberian jus kulit delima merah (Punica granatum) terhadap kadar LDL dan HDL wanita dislipidemia. Laki-laki memiliki risiko lebih tinggi dari pada perempuan yang belum mengalami menopause. Sebelum masa menopause, perempuan dilindungi oleh hormon estrogen. Hormon estrogen berfungsi untuk mencegah terbentuknya plak pada arteri dengan menaikkan kadar HDL dan menurunkan kadar LDL. ${ }^{11}$ Buah delima merah dalam penelitian ini dipilih sebagai bahan perlakuan karena kandungan anthocyanin pada buah delima merah lebih besar dari buah lainnya seperti buah apel merah, anggur merah dan strawberry. Kandungan anthocyanin pada buah delima merah sebesar $17 \mathrm{mg} / \mathrm{gram}$, apel merah sebesar $0,12 \mathrm{mg} / \mathrm{gram}$, anggur merah sebesar $0,26 \mathrm{mg} / \mathrm{gram}$ dan strawberry sebesar 0,21 $\mathrm{mg} /$ gram. $^{12,13}$

\section{METODE :}

Penelitian ini merupakan penelitian quasi experimental dengan rancangan pre-post control 
group design. Variabel terikat dalam penelitian ini adalah kadar kolesterol LDL dan HDL penderita dislipidemia, sedangkan variabel bebas adalah kulit buah delima.

Subyek Penelitian diambil pada bulan September 2013 di Kantor Dinas Perhubungan, Komunikasi dan Informatika (DINHUBKOMINFO) Provinsi Jawa Tengah, Kota Semarang. Kriteria inklusi adalah wanita usia 30-49 tahun yang memiliki kadar kolesterol LDL $\geq$ $130 \mathrm{mg} / \mathrm{dl}$ dan kadar kolesterol HDL $\leq 40 \mathrm{mg} / \mathrm{dl}$, bersedia menjadi subyek penelitian, tidak sedang mengkonsumsi obat antihiperlipidemia dan tidak dalam keadaan sakit atau perawatan dokter, belum menopouse serta tidak dalam keadaan hamil atau menyusui. Perhitungan subyek penelitan menggunakan rumus uji hipotesis terhadap rerata dua populasi independen dan dibutuhkan sebanyak 16 subyek.

Pemilihan subjek menggunakan metode simple random sampling. Subjek 53 orang bersedia diambil darahnya untuk proses skrining awal dan diperoleh sebanyak 18 orang yang memenuhi kriteria inklusi, namun hanya 16 orang yang diambil untuk subyek penelitian. Subyek dibagi menjadi 2 kelompok dengan metode random, yang terdiri atas kelompok kontrol dan kelompok perlakuan, masing-masing kelompok terdiri atas 8 subyek. Kelompok kontrol diberikan placebo yaitu sirup bebas kalori 1 sendok makan/kemasan dan kelompok perlakuan kulit delima dosis 25 gram/orang/hari selama 14 hari, ditambahkan air $200 \mathrm{cc}$ dan sirup bebas gula 3 sendok makan, kemudian diblender sampai halus. Hasil setelah diblender terdapat endapan yang kemudian disaring dan endapan tidak diberikan pada saat perlakuan dan selanjutnya dikemas menggunakan gelas disposable.

Pemberian kulit buah delima dan placebo dilakukan selama 14 hari berturut-turut pada hari kerja maupun libur. Asupan zat gizi subjek dicatat menggunakan recall 24 jam setiap hari selama penelitian berlangsung. Satuan yang digunakan untuk asupan energi kalori (kkal), asupan protein, lemak, karbohidrat, dan serat dalam gram (g), dan satuan asupan kolesterol milligram (mg). Perhitungan asupan energi, protein, lemak, karbohidrat, serat dan kolesterol menggunakan nutrisurvey 2005. Aktivitas fisik subjek diukur menggunakan dicatat menggunakan international physical activity questionnaire (IPAQ).

Data kadar kolesterol LDL dan HDL diambil oleh petugas laboratorium menggunakan metode perhitungan dan phosphotungstic parcipitation setelah subyek berpuasa selama \pm 10 jam.

Uji normalitas rerata asupan energi, protein, lemak, karbohidrat, serat dan kolesterol, aktivitas fisik, kadar LDL dan HDL sebelum dan setelah perlakuan, perubahan kadar LDL dan HDL menggunakan uji Shapiro-Wilk. Uji beda kadar LDL dan HDL sebelum dan setelah perlakuan pada kelompok perlakuan menggunakan uji dependent $t$ test dan uji beda kadar kolesterol LDL dan HDL sebelum dan setelah perlakuan pada kelompok kontrol menggunakan uji non parametric Wilcoxon.

\section{HASIL PENELITIAN : \\ Karakteristik subjek}

Penelitian ini melibatkan 16 wanita yang merupakan pegawai di Kantor Dinas Perhubungan, Komunikasi dan Informatika (DINHUBKOMINFO) Provinsi Jawa Tengah, Kota Semarang. Rerata usia subjek 42 tahun. Subjek memiliki nilai rerata IMT pada kelompok perlakuan sebesar $25,55 \mathrm{~kg} / \mathrm{m}^{2}$ (obesitas) dan kelompok kontrol sebesar $24,7 \mathrm{~kg} / \mathrm{m}^{2}$ (overweight). Karakteristik subjek yang terdiri dari umur dan status gizi disajikan pada (Tabel 1)

Tabel 1. Gambaran umur dan status gizi kelompok perlakuan dan kontrol

\begin{tabular}{|c|c|c|c|c|c|c|}
\hline \multirow[t]{2}{*}{ Variabel } & \multicolumn{2}{|c|}{$\begin{array}{c}\text { Perlakuan } \\
(\mathrm{n}=15)\end{array}$} & \multicolumn{2}{|c|}{$\begin{array}{c}\text { Kontrol } \\
(\mathrm{n}=15)\end{array}$} & \multicolumn{2}{|c|}{$\begin{array}{c}\text { Total } \\
(n=30)\end{array}$} \\
\hline & $\mathrm{n}$ & $\%$ & $\mathrm{n}$ & $\%$ & $\mathrm{n}$ & $\%$ \\
\hline \multicolumn{7}{|l|}{ Umur (tahun) } \\
\hline $30-39$ & 2 & 25 & 2 & 25 & 4 & 25 \\
\hline $40-49$ & 6 & 75 & 6 & 75 & 12 & 75 \\
\hline \multicolumn{7}{|l|}{ Status Gizi } \\
\hline Normal & 3 & 37,5 & 1 & 12,5 & 4 & 25 \\
\hline Overweight & 2 & 25 & 3 & 37,5 & 5 & 31,25 \\
\hline Obesitas & 3 & 37,5 & 4 & 50 & 7 & 43,75 \\
\hline \multicolumn{7}{|c|}{$\begin{array}{l}\text { Aktivitas fisik subjek } \quad \text { (MET- } \\
\text { min/minggu) }\end{array}$} \\
\hline Ringan $<600$ & 3 & 37,5 & 0 & 0 & 3 & 18,75 \\
\hline
\end{tabular}




\begin{tabular}{lccccccc}
\cline { 2 - 6 } Sedang & $\mathbf{3} 600-2999$ & 5 & 62,5 & 8 & 100 & 13 & 81,25 \\
Berat $\geq 3000$ & 0 & 0 & 0 & 0 & 0 & 0 \\
\hline
\end{tabular}

Pada Tabel 1 menjelaskan penelitian ini sebagian besar diikuti subjek berumur 40-49 tahun. Status gizi subjek berdasarkan IMT pada kedua kelompok terdapat $31,25 \%$ overweight dan $43,37 \%$ obesitas. Aktivitas fisik subjek pada kedua kelompok terdapat $18,75 \%$ dalam kategori ringan dan $81,25 \%$ dalam kategori sedang.

\section{Asupan zat gizi selama perlakuan}

Asupan zat gizi subjek yang diperoleh dari makanan, minuman, dan suplemen meliputi asupan energi, protein, lemak, karbohidrat, serat, dan kolesterol. Data tersebut disajikan dalam bentuk persentase tingkat kecukupan (Tabel 2 dan 3)

Tabel 2. Gambaran tingkat kecukupan zat gizi kelompok perlakuan dan kontrol

\begin{tabular}{lccccccc}
\hline \multicolumn{1}{c}{$\begin{array}{c}\text { Variabel } \\
(\text { mean } \pm \text { SD) }\end{array}$} & \multicolumn{3}{c}{ Perlakuan $(\mathrm{n}=8)$} & \multicolumn{3}{c}{ Kontrol $(\mathrm{n}=8)$} \\
\cline { 2 - 6 } & Minimal & Maksimal & Rerata & Minimal & Maksimal & Rerata & $\mathrm{P}^{*}$ \\
\hline Tingkat kecukupan (\%) & & & & & & & \\
Energi & 94,69 & 117,24 & $103,71 \pm 7,28$ & 86,68 & 128,27 & $06,40 \pm 12,63$ & 0,61 \\
Protein & 91,17 & 116,04 & $101,84 \pm 8,03$ & 78,52 & 134,00 & $07,40 \pm 16,76$ & 0,41 \\
Lemak & 90,04 & 126,86 & $108,69 \pm 10,37$ & 77,76 & 142,86 & $06,87 \pm 19,20$ & 0,81 \\
Karbohidrat & 86,04 & 124,29 & $102,11 \pm 14,37$ & 92,11 & 118,79 & $102,56 \pm 9,42$ & 0,94 \\
Serat & 20,04 & 33,36 & $27,68 \pm 4,81$ & 25,64 & 58,08 & $34,28 \pm 10,48$ & 0,13 \\
Kolesterol & 47,61 & 214,40 & $101,36 \pm 14,37$ & 77,70 & 115,18 & $00.05 \pm 11,85$ & 0,94 \\
\hline
\end{tabular}

*independent $t$-test

Tabel 2 menjelaskan bahwa rerata tingkat kecukupan zat gizi meliputi asupan energi, protein, lemak, karbohidrat, serat dan kolestrol subjek pada kelompok perlakuan dan kontrol tidak terdapat perbedaan $(\mathrm{p}>0,05)$.

Tabel 3. Tingkat kecukupan asupan energi, protein, lemak, karbohidrat, serat dan kolesterol kelompok perlakuan dan kontrol

\begin{tabular}{|c|c|c|c|c|c|c|}
\hline \multirow[t]{2}{*}{ Asupan zat gizi selama perlakuan } & \multicolumn{2}{|c|}{$\begin{array}{c}\text { Perlakuan } \\
(\mathrm{n}=8)\end{array}$} & \multicolumn{2}{|c|}{$\begin{array}{c}\text { Kontrol } \\
(n=8)\end{array}$} & \multicolumn{2}{|c|}{$\begin{array}{c}\text { Total } \\
(\mathrm{n}=16)\end{array}$} \\
\hline & $\mathrm{n}$ & $\%$ & $\mathrm{n}$ & $\%$ & $\mathrm{n}$ & $\%$ \\
\hline \multicolumn{7}{|l|}{ Tingkat kecukupan energi } \\
\hline Berlebih $(>100 \%)$ & 5 & 62,5 & 5 & 62,5 & 10 & 62,5 \\
\hline Baik $(\leq 100 \%)$ & 3 & 37,5 & 3 & 37,5 & 6 & 37,5 \\
\hline \multicolumn{7}{|l|}{ Tingkat kecukupan protein } \\
\hline Berlebih $(>100 \%)$ & 6 & 75 & 6 & 75 & 12 & 75 \\
\hline Baik $(\leq 100 \%)$ & 2 & 25 & 2 & 25 & 4 & 25 \\
\hline \multicolumn{7}{|l|}{ Tingkat kecukupan lemak } \\
\hline Berlebih $(>100 \%)$ & 7 & 87,5 & 5 & 62,5 & 12 & 75 \\
\hline Baik $(\leq 100 \%)$ & 1 & 12,5 & 3 & 37,5 & 4 & 24 \\
\hline \multicolumn{7}{|l|}{ Tingkat kecukupan karbohidrat } \\
\hline Berlebih $(>100 \%)$ & 4 & 50 & 5 & 62,5 & 9 & 56,25 \\
\hline Baik $(\leq 100 \%)$ & 4 & 50 & 3 & 37,5 & 7 & 43,75 \\
\hline \multicolumn{7}{|l|}{ Asupan serat } \\
\hline Baik ( $\geq 25$ gram $)$ & 0 & 0 & 0 & 0 & 0 & 0 \\
\hline Kurang $(<25$ gram $)$ & 8 & 100 & 8 & 100 & 16 & 100 \\
\hline \multicolumn{7}{|l|}{ Asupan kolesterol } \\
\hline Berlebih $(>200)$ & 4 & 50 & 3 & 37,5 & 7 & 43,75 \\
\hline Baik $(\leq 200)$ & 4 & 50 & 5 & 62,5 & 9 & 56,25 \\
\hline
\end{tabular}

Tabel 3 menyebutkan bahwa asupan energi, protein, lemak, karbohidrat kelompok perlakuan dan kontrol sebagian besar dalam kategori berlebih. Asupan serat kelompok perlakuan dan kontrol $100 \%$ dalam kategori kurang. Asupan kolesterol kelompok perlakuan dan kontrol sebagian besar dalam kategori baik.
Perbedaan kadar LDL dan HDL sebelum dan sesudah perlakuan

Perbedaan perubahan kadar kolesterol LDL subjek pada kelompok perlakuan dan kontrol. Data tersebut disajikan dalam bentuk persen. (Tabel 4) 
Tabel 4. Perubahan kadar kolesterol LDL subjek

\begin{tabular}{lcccc}
\hline \multirow{2}{*}{ Kategori LDL } & \multicolumn{2}{c}{ Perlakuan } & \multicolumn{3}{c}{ Kontrol } \\
\cline { 2 - 5 } & $\mathrm{n}$ & $\%$ & $\mathrm{n}$ & $\%$ \\
\hline Naik & 3 & 37,50 & 3 & 37,50 \\
\hline Turun & 5 & 62,50 & 5 & 62,50 \\
\hline Total & 8 & 100 & 8 & 100 \\
\hline
\end{tabular}

Tabel 4 menyebutkan bahwa pada kelompok perlakuan terdapat $5(62,50 \%)$ subjek yang mengalami penurunan kadar LDL dengan rerata penurunan sebesar $23,48 \mathrm{mg} / \mathrm{dl}$ sedangkan pada kelompok kontrol terdapat $5(62,50 \%)$ subjek yang mengalami penurunan kadar LDL dengan rerata penurunan dengan rerata yang lebih kecil yaitu $17,58 \mathrm{mg} / \mathrm{dl}$. Tetapi berdasarkan uji beda independent t-test perubahan kadar LDL pada kelompok perlakuan dan kontrol tidak terdapat perbedaan.

Perbedaan kadar kolesterol LDL pada kelompok perlakuan dan kontrol meliputi kadar kolesterol LDL sebelum dan setelah perlakuan dan perbedaan penurunan. Data tersebut disajikan dalam bentuk rerata. (Tabel 5)

Tabel 5. Perbedaan kadar LDL sebelum dan sesudah perlakuan

\begin{tabular}{lccc}
\hline \multicolumn{1}{c}{ Variabel } & Perlakuan $(\mathrm{n}=8)$ & Kontrol $(\mathrm{n}=8)$ & $\mathrm{p}$ \\
\cline { 2 - 3 } & Rerata \pm SD & Rerata \pm SD & \\
\hline Kolesterol LDL (mg/dl) & & & \\
Sebelum perlakuan & $176,17 \pm 26,80$ & $153,77 \pm 40,36$ & $0,21^{3}$ \\
Setelah perlakuan & $173,65 \pm 25,84$ & $149,21 \pm 29,49$ & $0,10^{3}$ \\
Perubahan & $-2,52 \pm 31,86$ & $-4,56 \pm 25,23$ & $0,88^{3}$ \\
$\mathrm{p}$ & $0,82^{1}$ & $0,48^{2}$ & \\
${ }^{1}$ dependent $t$-test & & & \\
${ }^{2}$ uji wilcoxon & & & \\
${ }^{3}$ independent $t$-test & & &
\end{tabular}

Tabel 5 menyebutkan bahwa tidak terdapat perbedaan kadar kolesterol LDL pada kedua kelompok baik sebelum maupun setelah perlakuan ( $>0,05)$. Pada penelitian kedua kelompok, rerata kadar kolesterol LDL sebelum dan setelah perlakuan tidak terdapat perbedaan $(\mathrm{p}>0,05)$. Kadar kolesterol LDL pada kelompok perlakuan dan kontrol mengalami penurunan. Rerata penurunan kadar kolesterol LDL pada kelompok perlakuan sebesar $2,52+31,86 \mathrm{mg} / \mathrm{dl}$ dan kelompok kontrol sebesar 4,56 $\pm 25,23 \mathrm{mg} / \mathrm{dl}$. Rerata penurunan kadar kolesterol LDL antara kelompok perlakuan dan kontrol tidak terdapat perbedaan ( $>>0,05)$.

Perbedaan perubahan kadar kolesterol LDL subjek pada kelompok perlakuan dan kontrol. Data tersebut disajikan dalam bentuk persen. (Tabel 6)

Tabel 6. Perbedaan kadar kolesterol HDL subjek

\begin{tabular}{lcccc}
\hline \multirow{2}{*}{ Kategori HDL } & \multicolumn{2}{c}{ Perlakuan } & \multicolumn{2}{c}{ Kontrol } \\
\cline { 2 - 5 } & $\mathrm{n}$ & $\%$ & $\mathrm{n}$ & $\%$ \\
\hline Naik & 5 & 62,50 & 1 & 12,50 \\
\hline Tetap & 0 & 0 & 3 & 37,50 \\
\hline Turun & 3 & 37,50 & 4 & 50,00 \\
\hline Total & 8 & 100 & 8 & 100 \\
\hline
\end{tabular}

Tabel 6 menyebutkan bahwa pada kelompok perlakuan terdapat $5(62,50 \%)$ subjek yang mengalami kenaikan kadar HDL dengan rerata kenaikan sebesar 4,60 mg/dl sedangkan pada kelompok kontrol terdapat $1(12,50 \%)$ subjek yang mengalami kenaikan dengan rerata kenaikan yang lebih kecil yaitu sebesar 2,00 mg/dl. Tetapi berdasarkan uji beda independent t-test perubahan kadar HDL pada kelompok perlakuan dan kontrol tidak terdapat perbedaan.

Perbedaan kadar kolesterol HDL pada kelompok perlakuan dan kontrol meliputi kadar kolesterol HDL sebelum dan setelah perlakuan dan perbedaan penurunan. Data tersebut disajikan dalam bentuk rerata. (Tabel 7) 
Tabel 7. Perbedaan kadar HDL sebelum dan sesudah perlakuan

\begin{tabular}{cccc}
\hline \multicolumn{1}{c}{ Variabel } & Perlakuan $(\mathrm{n}=8)$ & Kontrol $(\mathrm{n}=8)$ & $\mathrm{p}$ \\
\cline { 2 - 3 } & Rerata $\pm \mathrm{SD}$ & Rerata \pm SD & \\
\hline Kolesterol HDL (mg/dl) & & & \\
Sebelum perlakuan & $42,00 \pm 4,53$ & $47,25 \pm 3,49$ & $0,02^{3}$ \\
Setelah perlakuan & $42,00 \pm 7,01$ & $45,00 \pm 5,26$ & $0,35^{3}$ \\
Perubahan & $0,00 \pm 6,80$ & $-2,25 \pm 3,80$ & $0,42^{3}$ \\
$\mathrm{p}$ & $1^{1}$ & $0,10^{2}$ & \\
\hline${ }^{1}$ dependent $t$-test & & & \\
${ }^{2}$ Uji wilcoxon & & & \\
${ }^{3}$ independent $t$-test & & &
\end{tabular}

Tabel 7 menyebutkan bahwa terdapat perbedaan kadar HDL pretest pada kelompok perlakuan dan kontrol $(\mathrm{p}<0,05)$, sedangkan pada kelompok kontrol tidak terdapat perbedaan ( $>0,05)$ Pada penelitian kedua kelompok, rerata kadar kolesterol HDL sebelum perlakuan terdapat perbedaan $(p<0,05)$, rerata kadar kolesterol HDL sebelum dan setelah perlakuan tidak terdapat perbedaan $(p>0,05)$. Rerata perubahan kadar kolesterol HDL pada kelompok perlakuan sebesar $0,00 \pm 6,80 \mathrm{mg} / \mathrm{dl}$ dan kelompok kontrol sebesar -
$2,25 \pm 3,80 \mathrm{mg} / \mathrm{dl}$. Rerata perubahan kadar kolesterol HDL antara kelompok perlakuan dan kontrol tidak terdapat perbedaan ( $p>0,05)$.

Pengaruh variabel perancu terhadap variasi kadar LDL sebelum dan setelah perlakuan

Variabel perancu dalam penelitian ini adalah asupan energi, protein, lemak karbohidrat, serat, kolesterol, dan faktor aktivitas fisik. Variabel yang mempunyai korelasi $<0,25$ diuji linier ganda meliputi asupan protein, karbohidrat dan lemak.

Tabel 8. Pengaruh variabel perancu terhadap variasi kadar LDL sebelum dan setelah perlakuan

\begin{tabular}{lccc}
\multicolumn{1}{c}{ Variabel } & Koefisien & Adjusted $\boldsymbol{R}$ square & $\boldsymbol{p}$ \\
\hline Asupan protein & 10,588 & \multirow{2}{*}{0,615} & 0,013 \\
Constan & $-470,019$ & & 0,013 \\
\hline
\end{tabular}

Hasil analisis variasi kadar LDL dapat dipengaruhi oleh asupan protein $(\mathrm{p}=0,013)$ dengan nilai koefisien asupan protein sebesar 10,588 dan constan -470.019 . angka adjusted $R$ square 0.615 menunjukan bahwa $61,5 \%$ variasi kadar LDL dapat dijelaskan oleh asupan protein.

\section{Pengaruh variabel perancu terhadap variasi} kadar HDL sebelum dan setelah perlakuan Variabel perancu dalam penelitian ini adalah asupan energi, protein, lemak karbohidrat, serat, kolesterol, dan faktor aktivitas fisik. Variabel yang mempunyai korelasi $<0,25$ diuji linier ganda yaitu asupan serat.

Tabel 9. Pengaruh variabel perancu terhadap variasi kadar HDL sebelum dan setelah perlakuan

\begin{tabular}{llcc}
\hline \multicolumn{1}{c}{ Variabel } & \multicolumn{1}{c}{ Koefisien } & Adjusted $\boldsymbol{R}$ square & $\boldsymbol{p}$ \\
\hline Asupan serat & 3,423 & 0,261 & 0,112 \\
Constan & $-23,690$ & & 0,116 \\
\hline
\end{tabular}

Hasil analisis variasi kadar HDL dapat dipengaruhi oleh asupan serat $(\mathrm{p}=0,112)$ dengan nilai koefisien asupan serat sebesar 3,423 dan constan -23,690 angka adjusted $R$ square 0.261 menunjukan bahwa 26,1\% variasi kadar HDL dapat dijelaskan oleh asupan serat.

\section{PEMBAHASAN}

Dislipidemia ditandai dengan peningkatan LDL dan penurunan HDL. Penurunan kadar kolesterol HDL dan peningkatan kadar kolesterol LDL dapat disebabkan beberapa faktor, yaitu diit, usia dan jenis kelamin, Indeks Massa Tubuh (IMT) dan aktivitas fisik. Pengaturan pola diit dan aktivitas fisik dapat meningkatkan kadar kolesterol HDL dan menurunkan kadar kolesterol LDL dengan cara mengontrol asupan zat gizi secara seimbang sesuai dengan kebutuhan yang berpedoman pada perhitungan dengan rumus mifflin untuk asupan energi, protein, lemak, kabohidrat, American Dietetic Association (ADA) untuk asupan serat dan National Cholesterol Education Program (NECP) untuk asupan kolesterol.

Responden penelitian ini adalah wanita usia 30-49 tahun yang diketahui belum mengalami menopause. responden dibagi menjadi dua kelompok yaitu kelompok perlakuan dan 
kelompok kontrol, kelompok perlakuan diberikan jus kulit buah delima sedangkan kelompok kontrol diberikan plasebo. Setiap kelompok terdiri dari 8 wanita usia 30-49 tahun yang mengalami dislipidemia dengan kadar $\mathrm{LDL} \geq 130 \mathrm{mg} / \mathrm{dl}$ dan kadar HDL $\leq 40 \mathrm{mg} / \mathrm{dl} .{ }^{4}$

Pada penelitian ini wanita 30-49 tahun sebagian besar memiliki status gizi overweight. Status gizi overweight dan obesitas memiliki risiko terjadinya penyakit jantung koroner lebih besar dibandingkan dengan status gizi underweight dan normal. Penderita obesitas terdapat kelainan hormon leptin yang dapat menggangu dalam mengontrol nafsu makan dan berdampak pada penyimpanan lemak dalam tubuh terganggu sehingga menimbulkan gangguan metabolisme lipoprotein yang ditandai dengan kadar trigliserida dan ester kolesterol meningkat, hal ini dapat menyebabkan terjadi penumpukan lemak berlebihan didalam tubuh dan meningkatkan kadar kolesterol. ${ }^{14,16,17}$

Status gizi overweight dan obesitas dapat dipengaruhi beberapa faktor yang salah satunya aktivitas fisik. Aktifitas fisik wanita yang diberikan jus kulit delima dan plasebo tidak terdapat perbedaan yang bermakna ( $p>0,05)$. Aktifitas yang teratur dan sesuai dengan energi expenditure dapat meningkatkan HDL, menurunkan LDL, trigliserida, tekanan darah dan sensitivitas insulin. Aktivitas fisik seperti olahraga teratur dapat memberikan pengaruh baik pada profil lipid plasma karena sensitifitas insulin meningkat yang ditandai dengan konsentrasi kolesterol LDL dan triasilgliserol menurun (konsentrasi kolesterol turun) sehingga disertai dengan meningkatnya ekskresi lipoprotein lipase. ${ }^{18}$

Hasil recall asupan zat gizi selama diberikan intervensi pada kelompok perlakuan dan kelompok kontrol tidak terdapat perbedaan ( $p>0,05)$. Asupan energi, protein, lemak, karbohidrat pada kelompok perlakuan dan kontrol sebagian besar dalam ketegori berlebih sedangkan untuk asupan serat kelompok perlakuan dan kontrol $100 \%$ dalam kategori kurang dengan rerata 7,74 g/hari. Jumlah ini masih dibawah hasil riset Puslitbang Gizi Depkes RI Tahun 2001, dimana rata-rata konsumsi serat penduduk Indonesia adalah 10,5 gram per hari. ${ }^{15}$

Kadar kolesterol LDL wanita yang diberikan jus kulit delima dari 8 wanita diketahui 3 diantaranya kadar kolesterol LDL dalam kategori naik. Kadar kolesterol LDL dalam kategori naik pada kelompok wanita yang diberikan jus kulit delima dapat disebabkan dari asupan karbohidrat, protein, dan kolesterol yang dikonsumsi lebih tinggi apabila dibandingkan dengan kelompok wanita yang tidak diberikan jus kulit delima. Kenaikan kadar kolesterol LDL dipengaruhi oleh asupan lemak jenuh, sedangkan pada penelitian tidak diketahui secara detail kandungan jenis lemak jenuh, lemak trans, lemak jenuh tunggal dan lemak tidak jenuh. Sementara American Heart Association 2006 merekomendasikan asupan lemak $20-25 \%$ dari total energi, yang terdiri dari lemak tak jenuh tunggal sampai $10 \%$, lemak tak jenuh ganda sampai $10 \%$, lemak jenuh dibawah $7 \%$ dan lemak trans dibawah $1 \%$ untuk mengurangi faktor risiko penyakit jantung. Salah satunya mengurangi terjadinya dislipidemia. ${ }^{1}$

Kadar kolesterol LDL sebelum diberikan jus kulit delima dan plasebo antara wanita yang diberikan jus kulit delima dan wanita yang diberikan plasebo tidak terdapat perbedaan $(\mathrm{p}=0,21)$. sehingga kadar kolesterol LDL setelah diberikan jus kulit delima dan plasebo antara wanita yang diberikan jus kulit delima dan wanita yang diberikan plasebo juga terdapat tidak terdapat perbedaan $(p=0,10)$. Pada kelompok perlakuan yang diberikan jus kulit delima kadar kolesterol LDL sebelum dan setelah diberikan jus kulit terdapat penurunan yang tidak bermakna $(\mathrm{p}=0,88)$.

Kadar kolesterol HDL wanita yang diberikan jus kulit delima dari 8 wanita diketahui 3 diantaranya kadar kolesterol HDL dalam kategori turun. Kadar kolesterol HDL dalam kategori turun pada kelompok wanita yang diberikan jus kulit delima dapat disebabkan dari asupan anthocyanin. Asupan anthocyanin yang rendah dapat menyebabkan penurunan kadar HDLyang dimana pada penelitian ini kadar asupan anthocyanin baik pada wanita yang diberikan jus kulit delima maupun wanita yang diberikan plasebo tidak diketahui secara detail berapa kandungan asupan anthocyanin, selain itu diketahui bahwa aktivitas fisik dapat mempengaruhi kadar HDL.

Kadar kolesterol HDL sebelum diberikan perlakuan antara wanita yang diberikan jus kulit delima dan wanita yang diberikan placebo terdapat perbedaan $(\mathrm{p}=0,02)$, namun kadar kolesterol HDL setelah diberikan perlakuan antara wanita yang diberikan jus kulit delima dan wanita yang diberikan plasebo juga terdapat tidak terdapat perbedaan $(\mathrm{p}=0,35)$. Pada kelompok perlakuan yang diberikan jus kulit delima, kadar kolesterol HDL sebelum dan setelah diberikan jus kulit delima tidak terdapat perubahan yang tidak bermakna $(p=0,42)$. Kadar kolesterol HDL wanita yang diberikan jus kulit delima tidak terdapat perubahan karena kadar kolesterol HDL wanita yang diberikan jus kulit delima dapat dipengaruhi 
dari kulit delima dosis 25 gram/orang/hari selama 14 hari mengandung anthocyanin. ${ }^{9,19}$ Mekanisme pengaruh anthocyanin dapat dijelaskan sebagai berikut, anthocyanin diketahui dapat menghambat enzim Cholesteryl Ester Transfer Protein (CETP) dalam proses katabolisme HDL sehingga kadar HDL dalam darah dapat meningkat. Peningkatan kadar HDL dapat mempengaruhi kadar kolesterol dalam darah, HDL berfungsi sebagai pengangkut kolesterol bebas dalam darah yang dibawa kembali ke hati dan selanjutnya dibuang lewat sekresi cairan empedu. ${ }^{20,21}$

Hasil uji regresi linier berganda diketahui bahwa asupan protein pada wanita yang diberikan jus kulit delima mempunyai pengaruh sebesar 61,5\% terhadap perubahan kadar kolesterol LDL. Berdasarkan asupan protein diketahuin bahwa wanita yang diberikan jus kulit delima kadar kolesterol LDL dalam kategori naik dapat disebebkan asupan protein yang tinggi. Asupan protein diketahui dapat mempengaruhi kadar LDL karena protein didalam tubuh dapat berikatan dengan kolesterol dan trigliserida kemudian membentuk kilomikron, yang berfungsi sebagai prekusor kolesterol LDL.

Wanita yang diberikan plasebo kadar kolesterol LDL sebelum dan setelah diberikan plasebo mengalami penurunan sebesar $4,56 \mathrm{mg} / \mathrm{dl}$ ( $>0,05)$. Penurunan kadar kolesterol LDL wanita yang diberikan plasebo seharusnya tidak mengalami penurunan karena plasebo yang diberikan berupa sirup bebas gula yang diketahui sirup bebas gula tersebut merupakan golongan gula alkohol jenis sorbitol dimana sorbitol tidak memiliki pengaruh terhadap kadar kolesterol LDL. Penurunan kadar kolesterol LDL baik wanita yang diberikan jus kulit delima dan wanita yang diberikan placebo dapat disebabkan dari asupan lemak karena pada penelitian ini asupan lemak tidak diketahui jenis lemak yang dikonsumsi, antaralain asupan lemak jenuh, lemak trans, lemak jenuh tunggal dan lemak tidak jenuh ganda.

Hasil uji regresi linier berganda diketahui bahwa asupan serat pada wanita yang diberikan jus kulit delima mempunyai pengaruh sebesar $26,1 \%$ terhadap perubahan kadar kolesterol HDL. Berdasarkan asupan serat diketahui bahwa wanita yang diberikan jus kulit delima kadar kolesterol HDL dalam kategori naik karena jus kulit delima yang mengandung anthocyanin juga mengandung serat hal ini yang dapat menyebabkan kadar kolesterol HDL pada kelompok perlakuan memiliki kadar HDL yang stabil.

\section{SIMPULAN}

Pemberian jus kulit buah delima selama 14 hari dengan dosis 25 gram/hari pada wanita dislipidemia tidak berpengaruh terhadap kadar LDL dan HDL. Namun terjadi penurunan kadar LDL sebesar 2,52 mg/dl sedangkan kadar HDL tidak terjadi perubahan.

\section{SARAN}

Pada penelitian selanjutnya perlu diketahui lebih detail jenis lemak yang dikonsumsi subjek selama penelitian. Terutama data jumlah asupan lemak jenuh, lemak trans, lemak jenuh tunggal dan lemak tidak jenuh ganda. Dilakukan uji untuk mengetahui kandungan serat dalam 25gram jus kulit buah delima. Penderita dislipidemia disarankan mengkonsumsi jus kulit delima dengan kulit delima dosis 25 gram/orang/hari karena dapat membantu menurunkan kadar LDL.

\section{DAFTAR PUSTAKA}

1. Krummel DA. Medical Nutrition Therapy for Cardiovascular Disease. In : L. Kathleen Mahan, Sylvia Escott-Stump, editors. Krause's Food and Nutrition Therapy. $12^{\text {th }}$ edition. Philadelphia, USA - Saunders Elsevier; 2008.p.833;61

2. Laporan Hasil Riset Kesehatan Dasar (RISKESDAS) Nasional 2007.

3. Profil Kesehatan Kota Semarang. Laporan Kematian Akibat Penyakit Tidak Menular. 2011.p. 58-59.

4. Soeharto I. Serangan Jantung dan Stroke. Jakarta : PT Gramedia Pustaka Utama, 2003.p.73-74

5. Simadibrata K, Siti S, editor. Ilmu Penyakit Dalam Jilid III. Edisi IV. Jakarta-Ilmu Adam JMF. Dislipidemia. Dalam : Aru W, Bambang S, Idrus A, Marcellus. Penyakit Dalam Fakultas Kedokteran UI; 2006.p.1926;31.

6. Laine C, Goldmann D. In the Clinic Dyslipidemia. Ann Intern Med ; 2007.

7. Yu Qin, Min Xia, Jing Ma, YuanTao Hao, Jing Liu, HaiYing Mou, et al. Anthocyanin supplementation improves serum LDL- and HDLcholesterol concentrations associated with the inhibition of cholesteryl ester transfer protein in dyslipidemic subjects. 2009.

8. Njoku V, Chidi O. Phytochemical constituents of some selected medicinal plants. O. Department of Chemistry, Imo State University, Owerri, Nigeria. Department of Pure and Industrial Chemistry, University of Port Harcourt, Port Harcourt, Nigeria. 2009; 3 (11): 228-233

9. Elfalleh W, Hannachi H, Tlili N, Yahia Y, Nasri N, Ferchichi A. Total phenolic contents and antioxidant activities of pomegranate peel, seed, leaf and flower. Departement de Biologie, Faculte des Sciences de Tunis, Universite de Tunis El 
Manar. Journal of Medical Plants Research 2012; 6: pp 4724-4730.

10. Osman HF, EshakMG, El-Sherbiny EM, Bayoumi MM. Biochemical and genetical evaluation of pomegranate impact on diabetes mellitus induced by alloxan in female rats. Radioisotopes Departement, Nuclear Research Center. Sci J 2012;9(3):1543-1553.

11. Le D, Garcia A, Lohsoonthorn V, Williams MA. Prevalence and risk factors of hypercholesterolemia among Thai men and women receiving health examinations. Southeast Asian J Trop Med Public Health. 2006; Vol 37:No.5.

12. Elfalleh W, Hannachi H, Tlili N, Yahia Y, Nasri $\mathrm{N}$, Ferchichi A. Total phenolic contents and antioxidant activities of pomegranate peel, seed, leaf and flower. Departement de Biologie, Faculte des Sciences de Tunis, Universite de Tunis El Manar. Journal of Medical Plants Research 2012;6.pp.4724-4730.

13. Xianli Wu, Beecher GR, Holden JM, Haytowitz DB, Gebhardt SE, Prior RL. Concentrations of Anthocyanins in Common Foods in the United States and Estimation of Normal Consumption. J. Agric. Food Chem. 2006; Vol 54: 4069-4075

14. Samsukhidir SNAB. Determination of Antioxidant Activity And Nutrient Composition of Pomegranate Peel (Punica granatum). Food Science and technology In the Faculty of Applied Sciences, University Teknologi MARA, Malaysia; 2012. Available from: URL: http://eprints.uitm.edu.my/4997/1/SITI NOR \%E F\%BF\%BD\%2580\%2598ADILAH BINTI SAM SUKHIDIR 12_24.pdf

15. Andrea A. Aspek medis Penyakit Jantung dan Pembuluh Darh. Dalam : Pertemuan Ilmiah Nasional ke-3 : 2007 Juli 19-21; Semarang. Asosiasi Dietisien Indonesia DPD JAwa Tengah; 2007

16. Kane JP, Malloy MJ. Gangguan metabolisme lipoprotein. Dalam: Greenspan FS, Baxter JD, editor. Endokrinologi dasar dan klinik. Edisi 4. Alih bahasa: Wijaya C, Maulany RF, Samsudin S. Dalam: Kartini A, Mandera LI, Sadikin V, editor. Jakarta: EGC, 2000.p.847-56.

17. Brewer HB. Increasing HDL cholesterol levels. New Engl J Med. 2004.15.p.350.

18. Executive Summary of the Third Report of the National Cholesterol Education Program (NCEP) Expert Panel on Detection, Evaluation, and Treatment of High Blood Cholesterol in Adults (Adults Treatment Panel III). [serial online]2002[cited 2013 May 2] Available from: URL:

http://www.nhlbi.nih.gov/guidelines/cholesterol/at p3full.pdf

19. Wiseman G. Nutrition \& Health. London: Taylor \& Francis. 2002.p.198
20. Mann J, Stewart A T. Essential of Human Nutrition Third Edition. USA : Oxford University. In press 2007.p.637.

21. Karyadi E. Kiat Mengatasi Diabetes, Hiperkolesterolemia, Stroke. Jakarta: PT Intisari Mediatama; 2006: 53-70,59-61,63-4,73. 